\title{
Sustainability of Digital Payments: Empirical Evidence from India
}

\author{
Dr. Vandana Bhavsar ${ }^{1}$, Dr. Pradeepta Kumar Samanta ${ }^{2}$ \\ ${ }^{I}$ Sr. Associate Professor, National Institute of Construction Management and Research, Pune. \\ Email ID: vandanabbhavsar@gmail.com \\ ${ }^{2}$ Sr. Associate Professor, National Institute of Construction Management and Research, Pune. \\ Email ID: samanta.pk@gmail.com \\ *Corresponding author-vandanabbhavsar@gmail.com
}

\begin{abstract}
The digital financial services like mobile money, digital payments, and newer digital payment systems or financial technologies when rendered productively and responsively in a structured environment, will enable growth and faster achievement of Sustainable Development Goals (SDGs) for a country. In recent years, the digital payment transactions in India have seen exponential growth in India due to massive drive by the Government of India's "Digital India" programme. Further, in India, using digital payment systems has become cost effective. Simultaneously, however, the growth of currency demand has also increased tremendously in the country. There is thus a need to understand whether the digital payments are sustainable in India. This study thus tries to investigate the reasons resulting to sustainability of digital payments over the period of 2011-12: Q12020-21: Q1. To explore this relationship, the study uses autoregressive distributed lag model (ARDL) bounds test to cointegration along with Dynamic ordinary least square method (DOLS). Empirical evidence revealsthat national income and economic shocks (demonetisation and pandemic) have significant positive on sustainability of digital payment transactions both in value and volume terms, whereas mobile payments are substitutes and hence negatively affect digital payments. Surprisingly, financial inclusion (proxied by the growth in bank accounts) is not found to have any role in sustainability of digital payments. Insights from the results signify impact on development in the direction of growing need for financial exposure by way of financial literacy and rising economic growth using positive shocks to advance digital payments in India.
\end{abstract}

Keywords. Digital payments; Digital payment infrastructure, autoregressive distributed lag model, financial inclusion, Sustainable Developmental Goals

\section{INTRODUCTION}

Sustainable development is the central idea that revolves around integrating both short and long-term issues of economics, society and environment (Streurer et al. 2005). Financial inclusion is considered as an economic instrument of inclusive growth and sustainable development. The Global Findex Database 2017 highlights the emerging benefits and status of financial inclusion through digital payments. World over, research studies suggest that digitising payments can further improve the efficiency by increasing the speed of payments and reducing the cost of disbursement. This also led to substantial increase in formal savings. But at the same time the successful implementation of digitisation depends heavily on the necessary technological infrastructure; for example, steady electricity and mobile networks and financial infrastructure which comprises an acceptable payment structure and a physical network to deliver payments. Consumers utilising digital payments are required to be assured to put and draw money securely, credibly and comfortably at cash-in and cash-out points. To ensure the benefits from digital financial services, the governments need to implement appropriate regulations and consumer protection safeguards.

With an objective to foster Digital Payments and convert India to a cash free society, plenty of strategies and implementation initiatives are undertaken by the Government so as to procure, offer services and disbursement of digital payments in India. Table 1 shows the trend of different payment instruments (in value of transaction) in India. As per Reserve Bank of India (RBI) report 2020, the percentage of digital transactions in the total non-cash retail 
Table 1: Trends in different Payment Instruments

\begin{tabular}{|c|c|c|c|c|}
\hline \multirow{2}{*}{\multicolumn{2}{|c|}{ Item }} & \multicolumn{3}{|c|}{ Value (Rs. Crore) } \\
\hline & & 2015-2016 & 2018-19 & 2019-20 \\
\hline \multicolumn{2}{|c|}{ Total digital payments $(1+2+3+4+5)$} & 92038329 & 163852286 & 162305934 \\
\hline 1. & Large Value Credit Transfers - RTGS & 82457801 & 135688187 & 131156475 \\
\hline \multirow[t]{2}{*}{2.} & Credit $\quad$ Transfers $\quad$ (AePS & 8901828 & 26097655 & 28572100 \\
\hline & $\begin{array}{l}\text { Transfers, APBS, ECS Cr, IMPS, NACH Cr, NEFT, } \\
\text { UPI) }\end{array}$ & & & \\
\hline 3. & $\begin{array}{l}\text { Debit Transfers and Direct Debits (BHIM Aadhaar } \\
\text { Pay, ECS Dr, NACH Dr., NETC) }\end{array}$ & 230354 & 656233 & 826036 \\
\hline 4. & Card Payments (Credit cards, Debit cards) & 399588 & 1196888 & 1535765 \\
\hline 5. & $\begin{array}{l}\text { Prepaid Payment Instruments (wallet, PPI cards, paper } \\
\text { vouchers) }\end{array}$ & 48758 & 213323 & 215558 \\
\hline \multicolumn{5}{|c|}{ Other Payment channels } \\
\hline 6. & Mobile Payments (mobile app based) & 404091 & 2958407 & 5781435 \\
\hline 7. & Paper-based Instruments (CTS, others) & - & 8246065 & 7824821 \\
\hline
\end{tabular}

Source: Reserve Bank of India

In nominal terms, the digital payments industry in India is projected to touch US\$ 700 billion transactions by 2022 . Further, the digital market is divided into types of digital payment system and region wise market. Mobile wallets, internet banking, mobile banking, Point of Sale, and others are different forms of digital payment system types. Whereas the region wise segmentation of digital payments covers urban and rural regions, with urban region holding the major market share at present. Figure 1 displays monthly trend of payment system infrastructure in India. The number of Point of Sale (POS) terminals, Automated Teller Machines (ATMs) and number of Bharat QR codes increased by 38.2 per cent, 3.08 percent and 74.6 percent respectively (RBI report 2020).

\section{Payment System Infrastructure}

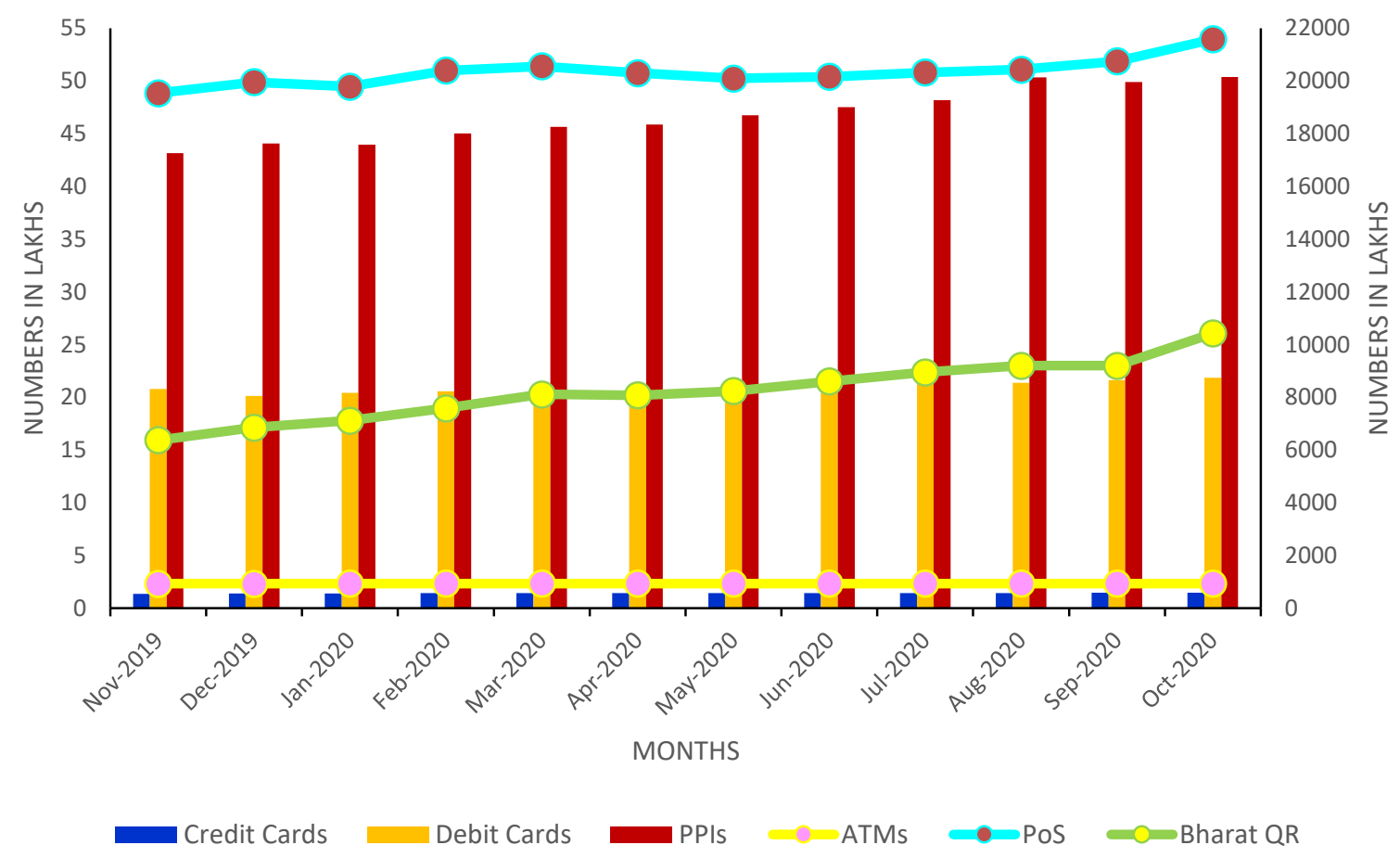

Source: RBI report 
There are several rationales for undertaking this investigation. First, in the economic literature, a high proportion of electronic payment transaction is believed to add to the economic development and also increases the competitiveness, as higher use of digital payments accelerate consumption expenditure in the economy, leading to higher production of goods and services, which ultimately propels economic growth of a country. Second, electronic payments further aid financial inclusion, by introducing formal financial services to those without an access to the formal banking. The central government is banking on the Digital India initiative to translate digitalised enabled Indian society and a knowledge intensive economy. By launching this initiative, the government's goal is to engage into conversation with the people living in the distant areas and thereby bring them into the growth story of India. Given that technology is a driving factor in initiating disturbing variation, digital technology will enable people and prove to be a game-changer. Third, although in India digital payments to GDP ratio did increase meaningfully post demonetisation, it is evident that the money supply to GDP ratio during the same period experienced an upward trend too (RBI Bulletin 2019). Further, international experience shows a slow transition to cashless economy and estimates that the boom in digital payment is for short period. Fourth, the enablers for digital payments in a country are mobile phones and internet, bank accounts, debit and credit cards, underlying digital infrastructure, efforts by the government, growth in the economic activity or growth in per capita income to name the few. Although, country level experiences suggest that these enablers do influence, facilitate and popularise the cashless transactions in a country, their impact on digital payment is not the same both in terms of its usage and popularity. A cross-country study by Bech et al. (2018) indicates that cash still remains the most preferred mode of transaction than digital payment transactions because of lower opportunity cost and store of value motive. These divergent experiences indicate ambiguity in the sustainability of digital payments and it thus becomes imperative to inspect the factors that lead to the sustainability of digital payments in India.

Given the above setting, the intent of this paper is to elucidate the semantics of sustainability of digital payments in India by addressing two research questions: a) what could be the indicators of sustainability of digital payments, and b) what are contributing factors driving sustainability of digital payments in India.
To achieve the above objective, unit root tests, autoregressive distributed lag (ARDL) approach to cointegration tests were employed, while for robustness, dynamic ordinary least square (DOLS) method was deployed. The reason to use ARDL bound test approach is because of its advantage over other cointegration tests. Also, long run coefficients from ARDL approach are super consistent for small sample data as in this study. The analytical results from these methodologies would throw light on adoption of policies that foster an integrated and harmonised digital payment and also to improve the sustainability of digital payments in the country.

\section{LITERATURE REVIEW}

Indian economy is predominantly a cash-driven economy. India's approach on digital finance is built upon four pillars (D’Silva et al. 2019): (i) supplying digital fiscal structures as a social good; (ii) reassuring private innovation by supplying license for such structures; (iii) generating equal opportunities for all through the regulatory framework; and (iv) authorizing people through a data-exchange infrastructure that needs their permission.

Sikdar and Kumar (2017) have investigated the role of payments banks as the digital payments instruments in achieving the financial inclusion goals. The paper indicates the benefits of payment banks compared to formal banking in providing the link to remotest location and thus provide the advantages to the unbanked and excluded demography. Another study made an effort to measure the financial inclusion in a amalgamated way to discover if the existing evidently main social and economic variables of financial inclusion as demonstrated in the vast literature are appropriate in a panel data analysis. The empirical examination employing a data of 28 Indian states concluded that growth, infrastructure and employment opportunities are possibly the utmost significant elements of financial inclusion (Nanda \& Samanta, 2018, Raichoudhury, 2020).

Gochhwal (2017) investigated at length regarding the Unified Payment Interface, the technic utilized and the addition of value that UPI produces in relation to the prevailing digital payment systems. The study attempts to decipher the technical architecture, transactional processes and security systems of UPI which can help to develop Innovative business solutions. All-encompassing finance directs to affluence and economic growth by eradicating or curtailing poverty, inequitable distribution of income 
and influence of indigenous bankers. Financial inclusion is by no means a one-dimensional process which might be accomplished instantly; instead, it is a method that finishes after various dimensions such as accessibility to and use of monetary facilities and finance penetration are completed. Dahiya and Kumar (2020) in their paper examined three main measures of financial inclusion: utilization, diffusion and user-friendliness to detect how financial inclusion is related with economic growth in India. The findings of the study reveal a substantial association among economic growth and the use dimension of financial inclusion in India.

Sing and Malik (2019) made an attempt to describe the scope and problems evolving in the local banking sector with particular focus on digitalization. The paper further analyzes the significance of digital competency in current banking set-up. Further it delivers the understandings of the digital techniques and methods approved by banks in rural India and to recognize the insights and performance of rural people concerning these services.

Arvind Panagariya (2019), in his research paper on digital revolution in India, has asserted that just accessibility of technology won't result into individuals to embracing it. The paper has given the instance of a high tax rates scenario wherein teams involved in a deal have an motivation to utilize cash to disburse payments and be safe generating a digital record of the dealings by making or accepting payment digitally. Thus, the paper underscores the importance of incentives to help permeate the digital revolution across the country.

\section{DATA AND METHODOLOGY}

\subsection{Data}

In order to formally gauge the sustainability of digital payments in India, the present study for empirical analysis uses the quarterly data from the period 2011-12: Q1-2020-21: Q1. The digital payment transactions as well as mobile banking transactions have been considered both in volume terms (real transactions) and in value terms (nominal transactions). The data on the real and nominal digital payments transactions (RDP and NDP), digital payment infrastructure (DI), real and nominal Mobile banking/payment (RMB and NMB), per capital net national income (PCNNI), growth in the bank accounts (ACT), growth in currency in circulation (CIC) are mainly sourced and assessed from official websites of Reserve Bank of India (RBI) and Centre for Monitoring Indian Economy (CMIE). Additionally, dummy variable (DV) assumes 1 for economic shocks (like demonetisation and current pandemic) and 0 otherwise.

Further as per RBI's payment system indicators, total digital payment is inclusive of large value and retail credit transfers, debit transfers, card payments and Prepaid Payment instruments but excludes mobile payment/banking, whereas digital payment infrastructure is inclusive of ATMs, POS, credit and debit card distributions. Hence in this study, mobile payment/banking is substitute to digital payments.

\subsection{Methodology}

The empirical approach viz., unit root and cointegration have been employed to investigate the linkage between digital payments and economic growth in India. Autoregressive distributed lag (ARDL) bounds approach to cointegration and dynamic ordinary least square analysis are directed to test the linkage between the variables. ARDL method advanced by Pesaran et al. (2001) was preferred upon other traditional cointegration test primarily because of its advantages viz., it is applicable even if the order of integration of variables is mixed, gives consistent and unbiased results even if the sample size is between 30 to 80 observations (Pesaran and shin, 1995) and gives simultaneous short and long run coefficients. Nevertheless, existence of I(2) causes this method improper; therefore, it is essential to examine for stationarity of variables. The unit root tests used are Augmented Dicky Fuller (ADF) (1979) and Kwiatkowski-Phillips-Schmidt-Shin (KPSS) (1992). The bounds test procedure in the unrestricted error correction model is employed so as to get short run and long run coefficients for cointegration relationships given as follows: 


$$
\begin{aligned}
\Delta R D P_{\mathrm{t}}=\alpha_{0}+ & \sum_{\mathrm{i}=1}^{\mathrm{k}} \beta_{\mathrm{i}} \Delta P C N N I_{\mathrm{t}-1}+\sum_{\mathrm{i}=1}^{\mathrm{k}} \theta_{\mathrm{i}} \Delta D I_{\mathrm{t}-1}+\sum_{\mathrm{i}=1}^{\mathrm{k}} \eta_{\mathrm{i}} \Delta \mathrm{RMB}_{\mathrm{t}-1}+\sum_{\mathrm{i}=1}^{\mathrm{k}} \varphi_{\mathrm{i}} \Delta A C T_{\mathrm{t}-1}+\sum_{\mathrm{i}=1}^{\mathrm{k}} \vartheta_{\mathrm{i}} \Delta C I C_{\mathrm{t}-1} \\
& +\sum_{\mathrm{i}=1}^{\mathrm{k}} \varphi_{\mathrm{i}} \Delta D V_{\mathrm{t}-1}+\pi_{1} P C N N I_{\mathrm{t}-1}+\pi_{2} D I_{\mathrm{t}-1}+\pi_{3} \mathrm{RMB}_{\mathrm{t}-1}+\pi_{4} A C T_{\mathrm{t}-1}+\pi_{5} C I C_{t-1} \\
& +\pi_{6} D V_{\mathrm{t}-1}+\varepsilon_{\mathrm{t}}(1) \\
\Delta N D P_{\mathrm{t}}=\alpha_{0}+ & \sum_{\mathrm{i}=1}^{\mathrm{k}} \beta_{\mathrm{i}} \Delta P C N N I_{\mathrm{t}-1}+\sum_{\mathrm{i}=1}^{\mathrm{k}} \theta_{\mathrm{i}} \Delta D I_{\mathrm{t}-1}+\sum_{\mathrm{i}=1}^{\mathrm{k}} \eta_{\mathrm{i}} \Delta \mathrm{NMB}_{\mathrm{t}-1}+\sum_{\mathrm{i}=1}^{\mathrm{k}} \varphi_{\mathrm{i}} \Delta A C T_{\mathrm{t}-1}+\sum_{\mathrm{i}=1}^{\mathrm{k}} \vartheta_{\mathrm{i}} \Delta C I C_{\mathrm{t}-1} \\
& +\sum_{\mathrm{i}=1}^{\mathrm{k}} \varphi_{\mathrm{i}} \Delta D V_{\mathrm{t}-1}+\pi_{1} P C N N I_{\mathrm{t}-1}+\pi_{2} D I_{\mathrm{t}-1}+\pi_{3} \mathrm{NMB}_{\mathrm{t}-1}+\pi_{4} A C T_{\mathrm{t}-1}+\pi_{5} C I C_{t-1} \\
& +\pi_{6} D V_{\mathrm{t}-1}+\varepsilon_{\mathrm{t}}(2)
\end{aligned}
$$

To study the long run relationship amongst the variables, following hypotheses are formulated- the null hypothesis of no cointegration $\left(\mathrm{H}_{0}: \pi_{1}=\pi_{2}=\right.$ $\pi_{3}=\pi_{4}=\pi_{5}=\pi_{6}=0$ ) is examined as opposed to the alternative hypothesis of the existence of cointegration relationship $\left(\mathrm{H}_{\mathrm{A}}: \pi_{1} \neq \pi_{2} \neq \pi_{3} \neq\right.$ $\pi_{4} \neq \pi_{5} \neq \pi_{6} \neq 0$ ). This is derived from F-test by ordinary least squares (OLS) estimation. Next the computed F-statistics value is matched with simulated critical bound values from Narayan (2005), created explicitly for small sample data. If the F-statistics is higher than the upper critical value,

$$
\begin{aligned}
\Delta \mathrm{RDP}_{\mathrm{t}}=\alpha_{0}+ & \sum_{\mathrm{j}=1}^{\mathrm{k}} \delta_{\mathrm{i}} \Delta \mathrm{R} D P_{\mathrm{t}-\mathrm{i}}+\sum_{\mathrm{j}=1}^{\mathrm{k}} \beta_{\mathrm{i}} \Delta P C N N I_{\mathrm{t}-\mathrm{i}}+\sum_{\mathrm{j}=1}^{\mathrm{k}} \theta_{\mathrm{i}} \Delta D I_{\mathrm{t}-\mathrm{i}}+\sum_{\mathrm{j}=1}^{\mathrm{k}} \eta_{\mathrm{i}} \Delta R M B_{\mathrm{t}-\mathrm{i}}+\sum_{\mathrm{j}=1}^{\mathrm{k}} \varphi_{\mathrm{i}} \Delta A C T_{\mathrm{t}-\mathrm{i}} \\
& +\sum_{\mathrm{j}=1}^{\mathrm{k}} \zeta_{\mathrm{i}} \Delta C I C_{\mathrm{t}-\mathrm{i}}+\sum_{\mathrm{j}=1}^{k} \psi_{\mathrm{i}} \Delta D V_{\mathrm{t}-\mathrm{i}}+\mu_{\mathrm{t}}(3) \\
\Delta R D P_{\mathrm{t}}=\alpha_{0}+ & \sum_{\mathrm{i}=1}^{k 1} \alpha_{\mathrm{DPi}} \Delta R D P_{\mathrm{t}-1}+\sum_{\mathrm{i}=1}^{k 2} \alpha_{\mathrm{PCNNIi}} \Delta P C N N I_{\mathrm{t}-1}+\sum_{\mathrm{i}=1}^{k 3} \alpha_{\mathrm{DIi}} \Delta D I_{\mathrm{t}-1}+\sum_{\mathrm{i}=1}^{k 4} \alpha_{\mathrm{ACTi}} \Delta A C T_{\mathrm{t}-1} \\
& +\sum_{\mathrm{i}=1}^{k 5} \alpha_{\mathrm{M} 1 \mathrm{i}} \Delta C I C_{\mathrm{t}-1}+\sum_{\mathrm{i}=1}^{k 6} \alpha_{\mathrm{DVi}} \Delta D V_{\mathrm{t}-1}+\sum_{\mathrm{i}=1}^{k} \alpha_{R M B i} \Delta R M B_{\mathrm{t}-1}+\xi_{1} \mathrm{ECT}_{1 \mathrm{t}-1} \\
& +\mathrm{v}_{1 \mathrm{t}}
\end{aligned}
$$

where ECT1 refers to error correction term

Likewise, same specification is taken NDP (equation 2) if there is evidence of cointegration. Overall, the ECTt -1 should be negative and between $0-1$. Generally, the ECTt -1 indicates the rate of the adjustment to converge back to its long-run equilibrium. For robustness to ARDL estimates, the null hypothesis of no long run cointegration can be rejected i.e. there exists cointegration relationships. Contrary, if the test statistics is lower than the lower critical value the null hypothesis is not rejected i.e. there is no cointegration. All the same, if the test statistics lie in the middle of lower and upper critical values the result is inconclusive. After the bounds test validates the cointegration among the variables, the long-run (Equation 3) and short-run (Equation 4) coefficients can be investigated.

Table 2: Unit root tests

\begin{tabular}{lllll}
\hline Variables & ADF & & KPSS & \\
\hline & Levels & Differenced & Levels & Differenced \\
\hline RDP & -0.13 & $-5.72^{*}$ & 0.72 & $0.18^{*}$ \\
NDP & -1.49 & $-4.44^{*}$ & 0.54 & $0.19^{*}$ \\
DI & -0.45 & $-4.03^{*}$ & 0.72 & $0.18^{*}$ \\
PCNNI & $-3.58^{*}$ & - & 0.69 & $0.31^{*}$
\end{tabular}




$\begin{array}{lllll}\text { RMB } & 1.84 & -3.55^{* *} & 0.74 & 0.35^{* *} \\ \text { NMB } & -1.76 & -4.12^{*} & 0.65^{* * *} & 0.45^{* *} \\ \text { CIC } & -8.30^{*} & - & 0.34^{* *} & - \\ \text { ACT } & -6.33^{*} & - & 0.24^{*} & -\end{array}$

Notes: Eviews 9 used for estimations.

*significant at $1 \%, * *$ significant at $5 \%$, *** significant at $10 \%$.

\section{FINDINGS AND DISCUSSIONS}

For the present analysis, primarily stationarity of all variables is inspected to ascertain their order of integration. In order to assess the stationarity, unit root tests passed out by ADF test and KPSS test are presented in table 2. The test regression includes a constant for the levels and for the first differences of the variables. It is evident from the results that all variables are either stationary for ADF and KPSS at levels or after first difference they are stationary. Hence, these variables are of mix order of integration.

Next to verify the existence of cointegration amongst the variables, equations (1) and (2) are calculated to arrive at F-statistics value and

Table 3: ARDL bounds test for cointegration

\begin{tabular}{clll}
\hline Test Statistic & F-statistic Value & K & Lags $^{\#}$ \\
\hline F(RDP|PCNNI, DI, ACT, RMB, CIC, DV) & $7.76^{*}$ & 6 & 1 \\
F(NDP|PCNNI, DI, ACT, NMB, CIC, DV) & $3.63^{* * *}$ & 6 & 2
\end{tabular}

Critical Value Bounds (Narayan, 2005)

\section{Significance level}

$10 \%$

$5 \%$

$1 \%$

$10 \%$

$5 \%$

$1 \%$

Notes: Eviews 9 used for estimations.

*significant at $1 \%$, *** significant at $10 \%$.

\# According to lag order selection criterion

Subsequent to confirming of long-run cointegrating relationship amongst the variables, equations (1) and (2) are assessed using ARDL specification. DOLS is also employed to examine the strength of long-run estimates attained from ARDL. The findings acquired from ARDL and DOLS estimations of the equations (1) and (2) are presented displayed in table 3. As noted previously, to reject the null hypothesis and accept the alternative hypothesis of existence of long run cointegration amongst variables, the $\mathrm{F}$ value should be greater than upper bound critical values.

The results in table 3 presents the computed Fstatistics to be higher than the upper bound critical value obtained from Table Case II in Narayan (2005). This indicates that rejection of null hypothesis, suggesting that there is long-run cointegrating relationship between digital payment and factors influencing the digital payment usage. To put it differently, the variables form steady long-run associations mutually. Although temporary there might be provisional disparities, in the long run there is equilibrium among the variables. 
The per capita net national income result corroborates with findings of Davies et al. (2016), Table 4: ARDL Long run estimates
Bech et al. (2018) and Stavins, (2001).

\begin{tabular}{lllll}
\hline \multirow{2}{*}{ Variables } & $\begin{array}{l}\text { Autoregressive } \\
\text { (ARDL) }\end{array}$ & Distributed lag model & $\begin{array}{l}\text { Dynamic ordinary least square method } \\
\text { (DOLS) }\end{array}$ \\
\cline { 2 - 5 } & $\begin{array}{l}\text { Dependent variable } \\
\text { RDP (Volume) }\end{array}$ & NDP (Value) & $\begin{array}{l}\text { Dependent variable } \\
\text { RDP (Volume) }\end{array}$ & NDP (Value) \\
\hline DI & 0.19 & $-0.77^{* *}$ & -0.02 & $-0.76^{*}$ \\
PCNNI & $3.74^{*}$ & $10.79^{*}$ & $3.88^{*}$ & $10.35^{*}$ \\
RMB (Volume) & -0.04 & - & 0.01 & - \\
NMB (Value) & - & $-0.31^{*}$ & - & $-0.30^{*}$ \\
CIC & $0.002^{* * *}$ & $0.02^{* * *}$ & $0.004^{*}$ & $0.02^{* *}$ \\
ACT & 0.004 & $0.11^{* *}$ & 0.001 & $0.08^{*}$ \\
DV & $0.31^{*}$ & $1.10^{* * *}$ & $0.18^{* * *}$ & $0.84^{* *}$ \\
C & $-35.16^{*}$ & $-91.65^{*}$ & $-34.05^{*}$ & $-87.65^{*}$
\end{tabular}

Note: Selected model of RDP $(1,0,0,0,0,0,0)$ and NDP $(1,2,2,2,2,2,2)$ based on Schwarz criterion (SIC).

*significant at $1 \%,{ }^{* *}$ significant at $5 \%, * * *$ significant at $10 \%$

Further, according to Mehta et al. (2016) and also as per RBI (2019), as a result of demonetisation, India experienced a transition from cash to digital cash. Similarly, the Covid-19 pandemic also directed to increase in usage of digital payments mainly due to concerns about viral transmission from cash. Interestingly, growth in currency in circulation (M1), though is significant has the least impact both on real and nominal digital payments. This indicates that India still has bias for cash payments mainly because people want to keep some money on hand for contingency purposes. Mobile banking both in real and nominal terms in long-run has negative impact on digital payments (real and nominal) signifying a substitution effect. In other words, an increase in mobile payments/banking means less use of cards and other digital payment instruments. Additionally, the long-run coefficient estimates of digital infrastructure though positive does not have impact on real digital payments whereas, it has negative and significant impact on nominal digital payments. This findings is in accordance with the findings of Deloitte's report (2016), which concludes that the digital infrastructure in India is more conducive for mobile and online payments than for digital instruments like (cards usage at POS, ATMs, etc.), and hence mobile banking/payment is substitute of digital payment instruments.

Last but not the least is the growth in bank accounts, which does not have any impact on the real growth of digital payments, however, it has positive impact on nominal growth of digital payments in the country. This indicates that just opening of bank account will not lead to more adoption or usage of digital payment instruments. According to Mukhopadhyay (2016), there exists strong positive relationship between receiving payments in the accounts and usage of digital payments. In India, despite government's efforts to open accounts under Pradhan Mantri JanDhan Yojna (PMJDY) to achieve financial inclusion objective, quarter of these accounts have zero-balance or lie dormant. There is thus no motivation to use digital payments.

Overall, the results indicate that in the long-run, in real terms it is only the income and economic shocks which may lead to the sustainability of the digital payments in the country, though in nominal terms apart from these two factors, growth in the bank accounts may also lead to sustainable digital payments. The DOLS estimation is to greater extent in line with ARDL estimates. After finding long-run coefficients, error correction model through equations (1) and (2) are assessed and it is anticipated to supplement long-run ARDL cointegration results.

Table 5: Short run Error Correction Model

\begin{tabular}{lll}
\hline Variables & \multicolumn{2}{l}{ Dependent Variable } \\
\hline & $\begin{array}{l}\text { RDP } \\
\text { (Volume) }\end{array}$ & $\begin{array}{l}\text { NDP } \\
\text { (Value) }\end{array}$ \\
\hline DI & 0.09 & -0.90015 \\
PCNNI & $1.73^{*}$ & $4.69^{* *}$ \\
RMB (Volume) & -0.02 & - \\
NMB (Value) & - & -0.01 \\
CIC & $0.001^{* * *}$ & $0.006^{* *}$ \\
ACT & 0.002 & $0.03^{*}$ \\
DV & $0.15^{* *}$ & $0.26^{* * *}$ \\
ECT (-1) & $-0.46^{* *}$ & $-0.73^{*}$ \\
Model diagnostics & & \\
F-statistics & $7.76^{* *}$ & $20.71^{*}$ \\
R-squared & 0.99 & 0.96 \\
Adj. R-squared & 0.99 & 0.92 \\
DW statistics & 1.78 & 1.98
\end{tabular}


$\begin{array}{lll}\text { Autocorrelation test } & 0.73 & 0.98 \\ \text { Heteroscedasticity test } & 1.51 & 0.76\end{array}$

Notes: *significant at $1 \%,{ }^{* *}$ significant at $5 \%$, $* * *$ significant at $10 \%$

Table 5 displays findings of the short-run ARDL coefficients. The short run results are to a greater extent consistent with the long-run estimates except for digital infrastructure which is neither significant for real nor for nominal digital payments. Further, the coefficient of ECTt-1 for RDP and NDP is negative and significant at $5 \%$ and $1 \%$ respectively. The imbalance in the short run is altered in the long run at speed of $46 \%$ for RDP and at a rate of $73 \%$ for NDP in the subsequent period. Additionally, the coefficient of determination (R2) amongst the variables is between $0.96-0.99$. The estimated shortrun coefficients were exposed to diagnostics test for consistency under Lagrange multiplier (LM) tests. There is no proof of serial correlation and Heteroscedasticity at 5\% level of significance.

In real terms, as directed by error correction estimates it emerges that enablers of digital payment slowly converge to long-run equilibrium, whereas, in nominal terms the enablers of digital payment speedily converge to long-run equilibrium. It is hence deduced that in India, the substitution effect of currency in circulation on digital payment is lower than the strong positive income effect, suggesting that the digital transactions are increasing rapidly.

\section{CONCLUSION}

In this study, an attempt is made to understand whether the digital payments are sustainable in India by empirically investigating the factors contributing to it. This study tries to inspect the factors determining the sustainability of digital payments over the period of 2011-12: Q1-2020-21: Q1. To explore this, the study uses autoregressive distributed lag model (ARDL) bounds test to cointegration along with Dynamic ordinary least square method (DOLS). The results indicate that in long run national income and shocks like demonetisation and covid-19, both emerge as main factors leading to sustainability of digital payments in value and volume terms. Mobile banking/payments may not increase the usage of digital payments like cards etc. indicating that it is a substitute of digital payments. Also, digital infrastructure is not found to be an important factor for sustainability of digital payments. Lastly, financial inclusion as proxied by the growth in bank accounts not necessarily leads to sustainability of digital payments.
The payment system in India is moving from issuance stage to acceptance stage. The usage of digital payments basically depends on demand side factors like strong demand for digital payments and supply side factors like resilient digital infrastructure, growth in bank accounts, etc. The digital infrastructure is still low and so is the number of digital transactions, whereas the mobile transactions are rapidly increasing. Hence to increase the acceptance of digital payments, firstly, financial literacy is very important. People must be made aware of the benefits and risks of digital payments and should also be educated about operating their bank accounts. Secondly, all government services, fees, utilities, tolls etc. should have digital payment options. Thirdly, allowing to withdraw small amount of cash from POS/QR. The implication is that mere availability of technology neither makes individual adopt to it nor is it a substitute for financial inclusion. There has to be rigorous efforts both by the government and central bank to make digital payments a divine experience.

\section{REFERENCES}

[1] A.K. Nanda, S. Samanta, Mainstreaming tribals through financial literacy - a review of literature, International Journal of Social

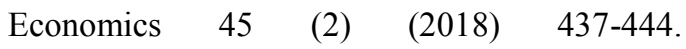
https://doi.org/10.1108/IJSE-12-2016-0371

[2] nnual Report, Reserve Bank of India, August 25, (2020), Government of India, New Delhi.

[3] Bech, M. L., Faruqui, U., Ougaard, F., \& Picillo, C. "Payments are a-changing but cash still rules". BIS Quarterly Review, March (2018).

[4] D’Silva, D., Filková, Z., Frank Packer and Tiwari, S. "The design of digital financial infrastructure: lessons from India" BIS Papers No. 106 (2019). Available at www.bis.org.

[5] Dahiya, S., and Kumar M. "Linkage between financial inclusion and economic growth: an empirical study of the emerging Indian economy." Vision. Vol 24 No 2 (2020), 184193 Sage Publications.

[6] Data on digital payment indicators accessed from https://dbie.rbi.org.in/DBIE/dbie.rbi? site=statist $\underline{\mathrm{ics}}$

[7] Data on per capita net national income accessed from 
https://economicoutlook.cmie.com/kommon/bin /sr.php?kall=wreport\&tabcode $=0010010080140$ 00000 \&oporder $=0$

[8] Davies, C., Doyle, M. A., Fisher, C., et al. "The future of cash". RBA Bulletin, December, (2016), 43-52.

[9] Deloitte "e-Commerece in India: a game changer"

https://www2.deloitte.com/content/dam/Deloitte /in/Documents/technology-media-

telecommunications/in-tmt-e-commerce-inindia-noexp.pdf

[10] Demirgüç-Kunt, Asli, Leora Klapper, et al. "The Global Findex Database 2017: measuring financial inclusion and the fintech revolution". (2018) Washington, DC: World Bank.

[11] Dickey, D.A. and Fuller, W.A. "Distribution of the estimators for autoregressive time series with a unit root." Journal of the American Statistical Association, Vol 74 No (366) (1979), pp:427-431. DOI: 10.2307/2286348.

[12] Dipak R. Chaudhari, Sarat Dhal et al. "Payment systems innovation and currency demand in India: some applied perspectives." Reserve Bank of India Occasional Papers Vol. 40, No 2, (2019), New Delhi.

[13] Gochhwal, R. "Unified payment interface-an advancement in payment systems". American Journal of Industrial and Business Management, 7 (2017), pp.1174-1191, Scientific Research Publishing.

[14] Herwadkar Snehal, Verma Radhesyam and Bilantu Prabal. "Drivers of digital payments: a cross country study." Reserve Bank of India Bulletin August (2019), New Delhi.

[15] Kao, C., Chiang, M.-H. "On the estimation and inference of a cointegrated regression in panel data". In: Baltagi, B., ed. Nonstationary Panels, Panel Cointegration, and Dynamic Panels. Advances in Econometrics, Vol. 15, (2000), Amsterdam: JAI Press, pp. 161-178.

[16] Kwiatowski Denis, Phillips Peter, et. al "Testing the null hypothesis of stationarity against the alternative of a unit root". Journal of Econometrics 54, (1992) 159-178.

[17] Mehta S, Patel K, Mehta K. "Demonetisation: shifting gears from physical cash to digital cash". Working papers (No. 2016-12-14) from
Voice of Research. (2016). http://EconPapers.repec.org/RePEc:vor:issues:2 016-12-14

[18] Mukhopadhyay, Bappaditya. "Understanding cashless payments in India, financial innovation". ISSN 2199-4730, Springer, Heidelberg, Vol. 2, No 27, (2016), pp. 1-26, http://dx.doi.org/10.1186/s40854-016-0047-4

[19] Narayan, P. "The saving and investment nexus for China: evidence from cointegration tests." Applied Economics, Vol. 37, No. 17, (2005), pp.1979-1990.

[20] Panagariya A. "Digital revolution, financial infrastructure and entrepreneurship: the case of India." Working Paper No. 2019-01 (2019), School of International and Public Affairs Columbia University New York.

[21] Pesaran, M.H. and Shin, Y. "An Autoregressive distributed lag modelling approach to cointegration analysis." DAE Working Paper Series No 9514, (1995), Department of Applied Economics, University of Cambridge, England.

[22] Pesaran, M.H., Shin, Y. and Smith, R.J. "Bounds testing approaches to the analysis of level relationships." Journal of Applied Econometrics, Vol. 16, (2001), pp:289-326.

[23] Raichoudhury, A. "Major Determinants of financial inclusion: state-level evidences from India". Vision. Vol 24, No 2, (2020),151-159. Sage Publications.

[24] Sikdar, P. and Kumar, A. "Payment Bank: a catalyst for financial inclusion". Asia-Pacific Journal of Management. Vol 12, No 3\&4, (2017), pp. 226-231. SAGE Publications.

[25] Singh, R. and Malik, G. "Impact of digitalization on Indian rural banking customer: with reference to payment systems". Emerging Economy Studies. Vol 5, No 1, (2019), pp. 3141. Sage Publications.

[26] Stavins, J. "Effect of consumer characteristics on the use of payment instruments". New England Economic Review. February (2001).

[27] Steurer R, Langer ME, Konrad A and Martinuzzi A. "Corporations, stakeholders and sustainable development: A theoretical exploration of business-society relations". Journal of Business Ethics 61, (2005), 263-281

[28] Stock, James H. and Mark W. Watson. "A simple estimator of cointegrating vectors in higher order integrated systems," Econometrica, Vol. 61, No. 4, July, (1993), 783-820. 